\title{
Pseudobunocephalus, a new genus of banjo catfish with the description of a new species from the Orinoco River system of Colombia and Venezuela (Siluriformes: Aspredinidae)
}

\author{
John P. Friel
}

Pseudobunocephalus, a new genus of small banjo catfishes ( $\leq 80 \mathrm{~mm} \mathrm{SL})$, is distinguished from all other aspredinid genera by the following unique features: mandibular teeth restricted to a patch near symphysis of lower jaw; no contact between the metapterygoid and quadrate; autopalatine posteriorly forked with two separate cartilages; absence of the fourth pharyngobranchial; absence of gill rakers on all branchial arches; and lack of bifid hemal spines on vertebrae that articulate with anal-fin pterygiophores. As defined Pseudobunocephalus contain a new species, P. lundbergi from the Orinoco River basin, along with five other species previously assigned to the genus Bunocephalus: P. amazonicus, P. bifidus, P. iheringii, P. quadriradiatus, and $P$. rugosus.

Pseudobunocephalus, gênero novo ( $\leq 80$ milímetros SL), se distingue de todos os outros gêneros de Aspredinidae pelas seguintes características: dentes mandibulares limitados a uma faixa perto da sínfise mandíbular; contato entre o metapterigóide e o quadrado ausente; autopalatino furcado posteriormente com duas cartilagens separadas; ausência do quarto faringobranquial; ausência de rastros em todos os arcos branquiais; e falta de espinhos hemais bífidos nas vértebras que se articulam com os pterigióforos da nadadeira anal. Conforme definido Pseudobunocephalus contém uma nova espécie, $P$. lundbergi da bacia do rio Orinoco, além de outras cinco espécies previamente atribuídas ao gênero Bunocephalus: $P$. amazonicus, $P$. bifidus, $P$. iheringii, P. quadriradiatus e $P$. rugosus.

Key words: Pseudobunocephalus amazonicus, Pseudobunocephalus bifidus, Pseudobunocephalus iheringii, Pseudobunocephalus quadriradiatus, Pseudobunocephalus rugosus.

\section{Introduction}

Fishes of the family Aspredinidae are commonly known as banjo catfishes due to their overall body shape, a depressed head and slender caudal peduncle, which when seen in dorsal view somewhat resembles the musical instrument (Myers, 1960). In addition to their body shape, most aspredinids are readily distinguished from other Neotropical catfishes by their heavily keratinized skins with rows of large unculiferous tubercles arranged along the dorsal surface and sides of their bodies. Representative species are found throughout the major tropical rivers of South America (e.g., Magdalena, Orinoco, Amazon, São Francisco, Paraguay-Paraná, and Uruguay), a few rivers west of the Andes Mountains (Atrato, San Juan, and Patia) and Atlantic drainages and coastal marine waters from the Orinoco to Amazon deltas. Aspredinids live in a va- riety of habitats ranging from shallow backwaters to deep river channels to tidal estuaries. Some aspredinids appear to be semi-fossorial, during the day often resting slightly buried in leaf litter or other soft substrates. In general, most species are cryptically pigmented, benthic, and rather sluggish unless disturbed.

As currently recognized the family Aspredinidae contains 36 species placed in 12 genera: Acanthobunocephalus (1 sp.), Amaralia (1 sp.), Aspredinichthys (2 spp.), Aspredo (1 sp.), Bunocephalus (14 spp.), Dupouyichthys (1 sp.), Ernstichthys (3 spp.), Hoplomyzon (3 spp.), Micromyzon (1 sp.), Platystacus (1 sp.), Pterobunocephalus (2 spp.), and Xyliphius (6 spp.) (Friel, 2003; Ferraris, 2007). Of these taxa, the genus Bunocephalus is the largest and most commonly represented in museum collections. An initial review of all aspredinid species for the author's dissertation research revealed a distinc- 
tive clade of species that had been placed in Bunocephalus, but were not closely related to the type species of this genus, Bunocephalus verrucosus (Walbaum, 1792) or any other nominal genera (Friel, 1994). This aspredinid clade is formally diagnosed and described here as a new genus along with the description of a new species from the Orinoco River basin.

\section{Material and Methods}

Methods generally follow those used in Friel (1995). Measurements were taken to the nearest $0.1 \mathrm{~mm}$ with digital calipers or from scaled distances between landmark points recorded with the aid of a stereomicroscope equipped with a camera lucida. All fish lengths are given as standard length (SL). Caudal peduncle depth was taken as the minimum depth of the caudal peduncle. Caudal peduncle length was taken from the posterior end of the anal-fin base to the end of the hypurals. Pectoral spine length does not include the flexible distal extension. Length of the postcleithral process was taken from the anterior insertion point of the erect pectoral spine with the pectoral girdle to the posterior tip of the process. Postcoracoid process length was taken from the transverse posterior margin of the pectoral girdle aside the base of the process to its tip. All lepidotrichia are included in the fin-ray counts. Stiffened dorsal- and pectoral-fin lepidotrichia are indicated by upper case Roman numerals. Observations on internal features were made from radiographs and/or cleared and stained specimens. Vertebral counts include the five fused vertebrae of the Weberian complex; the compound caudal centrum is counted as one. Institutional abbreviations follow Leviton et al. (1985).

Abbreviations used in anatomical figures are as follows: $\mathrm{ACF}$, anterior cranial fontanel; ACHY, anterior ceratohyal; BRR, branchiostegal rays; DEN, dentary; EDT, endopterygoid; FRT, frontal; HYO, hyomandibular; IOPR, interopercle; LET, lateral ethmoid; MET, mesethmoid; MTPT, metapterygoid; OPR, opercle; PCF, posterior cranial fontanel; POPR, preopercle; PTO, pterotic; QUA, quadrate; SCL, supracleithrum; SOC, supraoccipital; SPO, sphenotic; V4PP, parapophysis of vertebra 4; and V5PP, parapophysis of vertebra 5.

\section{Results}

\section{Pseudobunocephalus, new genus}

Type species. Pseudobunocephalus lundbergi new species by original designation. Gender: masculine.

Additional included species. Further nomenclatural details including junior synonyms for recognized species can be found in Friel (2003).

Pseudobunocephalus amazonicus (Mees, 1989)

Pseudobunocephalus bifidus (Eigenmann, 1942)

Pseudobunocephalus iheringii (Boulenger, 1891)

Pseudobunocephalus quadriradiatus (Mees, 1989)

Pseudobunocephalus rugosus (Eigenmann \& Kennedy, 1903)
Diagnosis. A genus of relatively small banjo catfishes (less than $80 \mathrm{~mm} \mathrm{SL}$ ) distinguished from other aspredinids by having the following unique characters: the dentary teeth are restricted to broad tooth patch near symphysis of lower jaw (Fig. 1) (vs. more broadly distributed along the length of the dentary); the metapterygoid lacks a bony connection with the quadrate (Fig. 1); the posterior end of autopalatine is distinctly forked and bears two separate terminal cartilages (Fig. 2); the absence of the fourth pharyngobranchial; the absence of gill rakers on all branchial arches; and the lack of bifid hemal spines on vertebrae that articulate with anal-fin pterygiophores.

Other characters not unique to this genus, but still useful for distinguishing it from other aspredinid genera include: the anterior limits of upper and lower jaws are approximately equal (also in Acanthobunocephalus); the lateral line is truncated at approximately the level of the dorsal-fin origin (also in Acanthobunocephalus); the dorsal- and ventral-most prin-

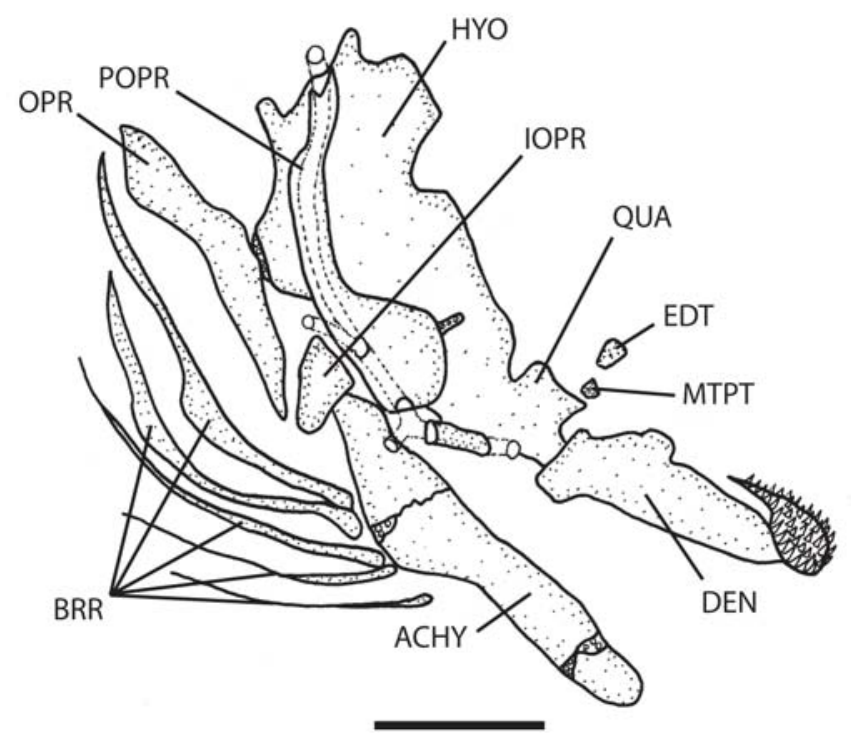

Fig. 1. Lateral view (anterior to the right) of the suspensorium, hyoid arch and lower jaw of Pseudobunocephalus lundbergi, ANSP 172505, paratype. Scale bar equals $1 \mathrm{~mm}$.

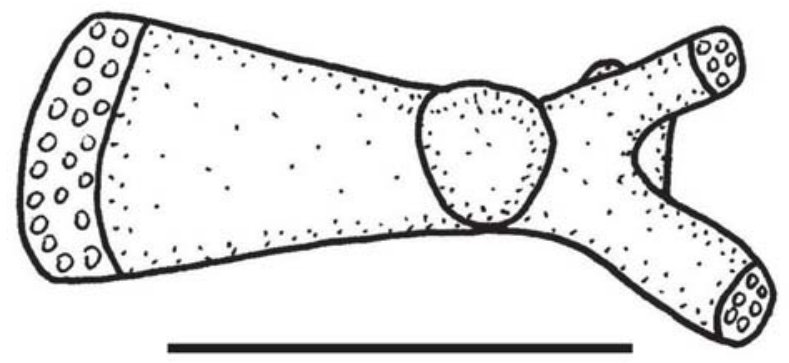

Fig. 2. Medial view (anterior to the left) of the autopalatine of Pseudobunocephalus lundbergi, ANSP 172505, paratype. Note forked posterior margin with two separate terminal cartilages (stippled with open circles). Scale bar equals $1 \mathrm{~mm}$. 
cipal caudal rays much shorter in length than other principal caudal rays (also in Acanthobunocephalus); the dorsal- and anal-fin membranes are not adnate with body (also in Acanthobunocephalus); the interhyal is absent (also in Hoplomyzon); and the abdominal and precaudal centra lack bony horizontal lamina (also in Dupouyichthys, Ernstichthys, Hoplomyzon and Micromyzon).

Etymology. The generic name is a combination of the Greek word pseudes, meaning false or deceptive, plus the aspredinid genus Bunocephalus. It alludes to the fact that members of this new genus have previously been mistaken for juveniles of various species of Bunocephalus.

\section{Key to species of Pseudobunocephalus.}

1a. Dorsal surface of skull ornamented with numerous bony knobs of equal size; epiphyseal bar present between frontals; infraorbital canal exits from sphenotic (Fig. 3), bears up to four pores, and extends anteriorly beyond eye (Orinoco basin) P. lundbergi

1b. Dorsal surface of skull relatively smooth or ornamented with longitudinal bony ridges bearing a few bony knobs; epiphyseal bar between frontals absent, and area between eyes concave; infraorbital canal exits from frontal, bears 1 or 2 pores, and does not extend anteriorly beyond eye .... 2

2a. Posterolateral mental barbels simple, without any accessory lobes

.... 3

2b. Posterolateral mental barbels with one or more fleshy lobes proximally along the posterior margin

3a. Overall pigmentation relatively uniform, without strong contrast between dark and light areas (Paraguay-Paraná basin) P. rugosus

3 b. Body pigmentation with strong contrast between dark and light areas.

4a. Pectoral fin with 5 soft rays (Amazon basin) .... P. amazonicus

4b. Pectoral fin with 4 soft rays (Amazon basin).

P. quadriradiatus

5a. Dorsal fin with flexible spine and 4 soft rays; pectoral fin with 5 soft rays (Amazon basin) P. bifidus

5 b. Dorsal fin with flexible spine and 3 soft rays; pectoral fin with 4 soft rays (Paraguay-Paraná, Uruguay and laguna dos Patos basins) P. iheringii

\section{Pseudobunocephalus lundbergi, new species} Fig. 4

Holotype. ANSP 168817, 28.4 mm SL, Venezuela, Bolivar, caño Barranca, approximately 1.25 hours downstream from Jabillal (opposite bank) on río Caura, $07^{\circ} 08^{\prime} \mathrm{N} 65^{\circ} 04^{\prime} \mathrm{W}, 30$ Jan 1977, J. Böhlke and W. Saul.

Paratypes. Venezuela, Bolivar, ANSP 172504, 10, 20.5-29.1 mm SL; ANSP 172505, 370 alcohol, 5 cleared \& stained, 20.0-30.0 mm SL; AUM 47713, 6, 22.7-24.7 mm SL; CU 94217, 8, 25.6-28.1 mm SL; FMNH 117789, 6, 20.5-27.1 mm SL; INPA 29030, 6, 20.5$26.5 \mathrm{~mm}$ SL; MBUCV-V-35369, 6, 21.2-26.1 mm SL; all same data as holotype; MCNG 21122, 3, 24.6-26.4 mm SL, forest stream 5

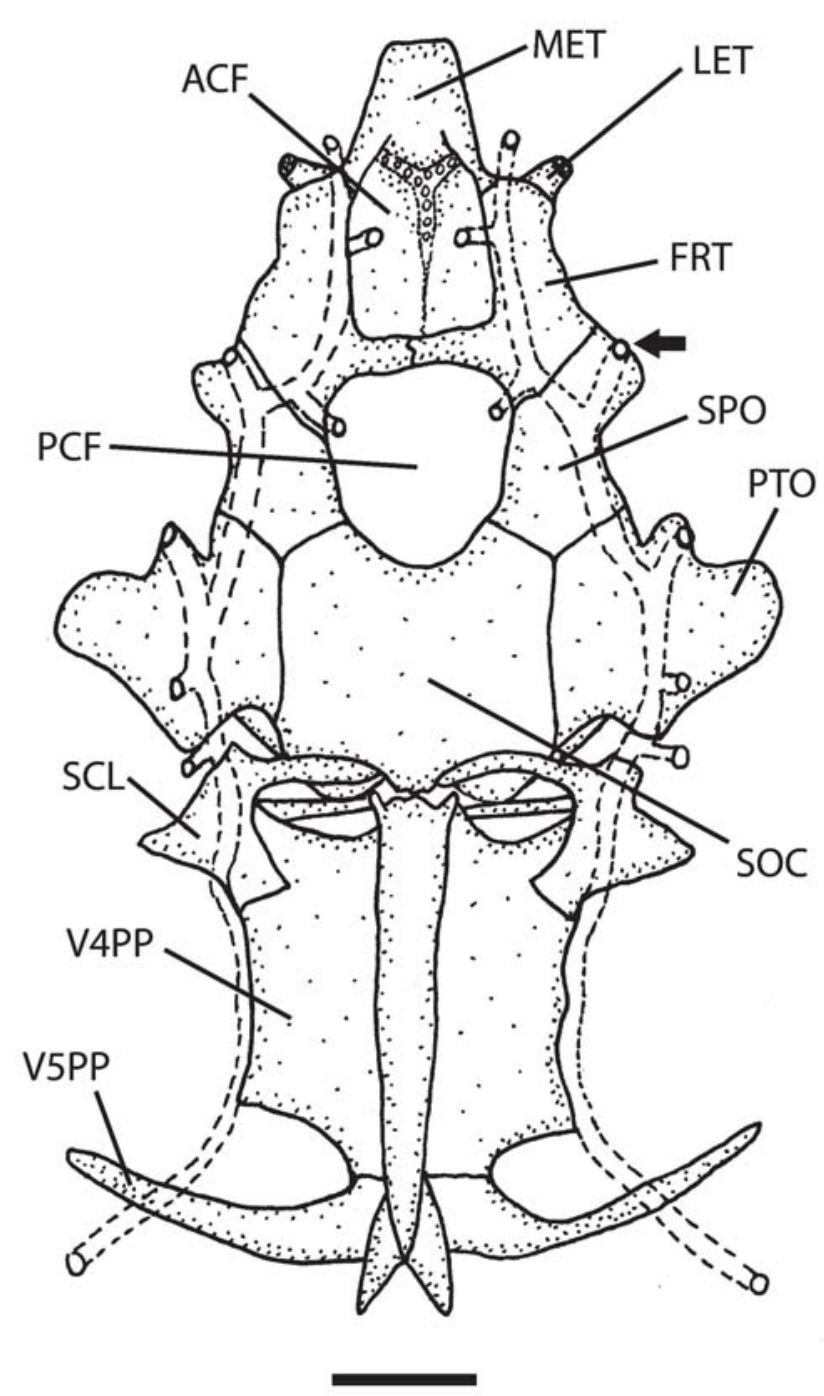

Fig. 3. Dorsal view of the neurocranium and Weberian complex of Pseudobunocephalus lundbergi, ANSP 172505. Arrow indicates the exit of the infraorbital canal from the sphenotic. Scale bar equals $1 \mathrm{~mm}$.

km N of Jabillal, 3 Mar 1989, D. Taphorn et al.; MCP 42737, 6, 22.6-25.4 mm SL; MZUSP 99617, 6, 20.5-25.1 mm SL; USNM 393553, 6, 18.8-24.6 mm SL, same data as holotype.

Non-types. Colombia, Meta, ANSP 131574, 4, 19.5-22.5 mm SL, caño Rico at La Defensa, $03^{\circ} 59^{\prime}$ N 730' $\mathrm{W}, 25$ Feb 1972, J. Böhlke et al.; ANSP 134530, 1, $24.3 \mathrm{~mm} \mathrm{SL}$, ca. $5 \mathrm{~km} \mathrm{~N}$ of La Siberia, $04^{\circ} 07^{\prime} \mathrm{N} 73^{\circ} 05^{\prime} \mathrm{W}, 28 \mathrm{Mar} 1975$, J. Böhlke et al.; ANSP 168815, 4, 22.0-23.0 mm SL, caño La Raya, N of La Siberia, $04^{\circ} 50^{\prime} \mathrm{N} 73^{\circ} 05^{\prime} \mathrm{W}$, 29 Mar 1975, J. Böhlke et al. Venezuela, Apure, MCNG 23671, 13 (12 alcohol, 1 cleared \& stained), 20.0-23.0 mm SL, río Meta between San Carlos de Meta and Buena Vista, 14 Jan 1982, D. Taphorn et al. Barinas, MCNG 23669, 2, 22.5-23 mm SL, Ticoporo forest, río Socopo basin, 9 Dec 1982, D. Taphorn et al.

Diagnosis. Pseudobunocephalus lundbergi can be distinguished from all congeners by having the following unique characters within the genus: dorsal surface of skull orna- 


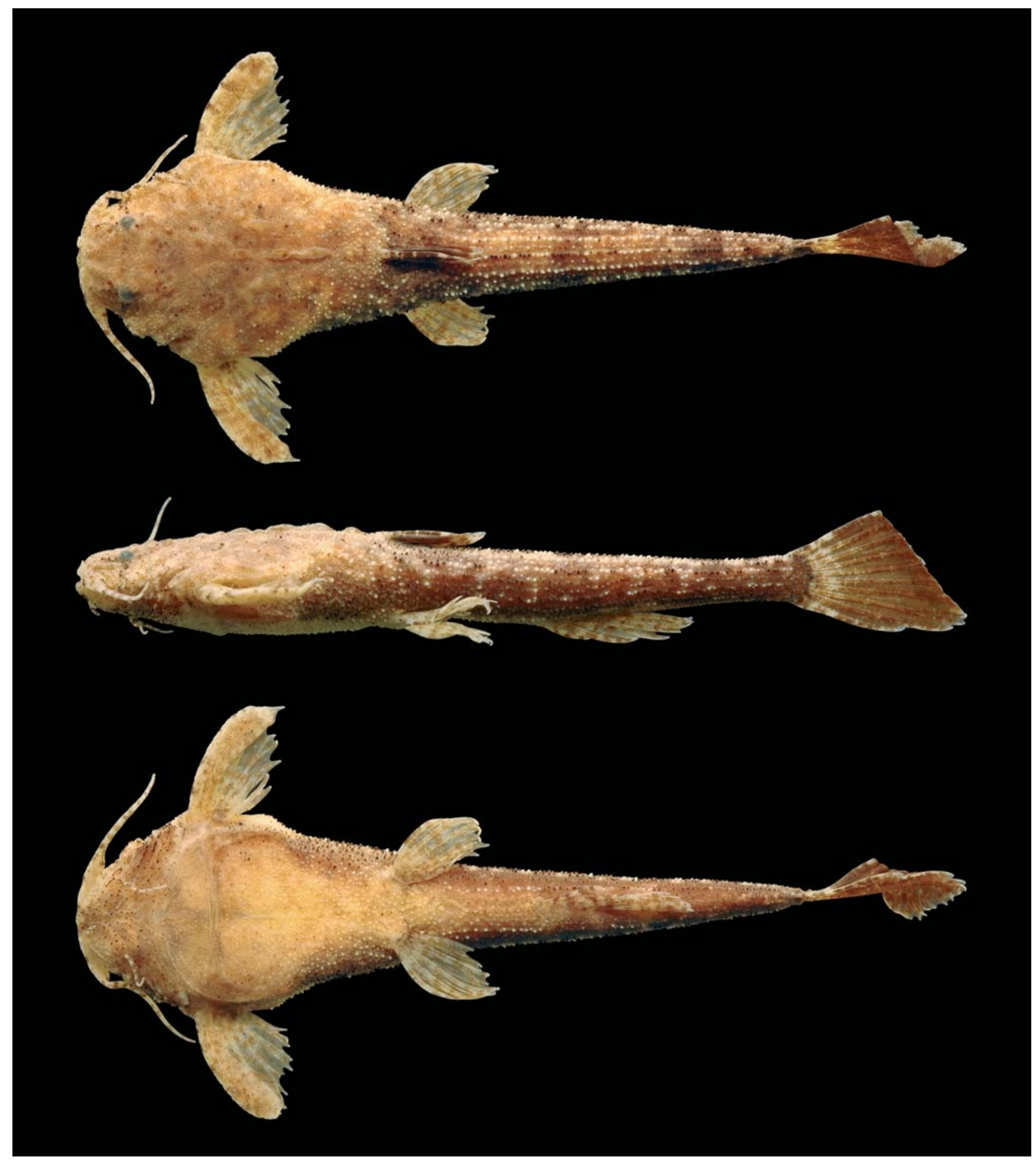

Fig. 4. Dorsal, lateral and ventral views of Pseudobunocephalus lundbergi, Holotype, ANSP 168817, 28.4 mm SL, Venezuela, Bolivar, caño Barranca, approximately 1.25 hours downstream from Jabillal (opposite bank) on río Caura ( $\left.07^{\circ} 08^{\prime} \mathrm{N} 65^{\circ} 04^{\prime} \mathrm{W}\right)$, collected by J. Böhlke and W. Saul, 30 Jan 1977. Note the caudal fin is normal and intact, but has been creased and folded in preservation. Photographs by T. R. Vigliotta.

mented with numerous bony knobs of equal size (Fig. 4); distinct anterior and posterior cranial fontanels separated by a bony epiphyseal bar formed between the frontals (Fig. 3); infraorbital canal exits from the sphenotic (Fig. 3) and extends anteriorly past eye, bearing up to four pores (not figured); premaxilla without a posterolateral limb; and fifth centra with posteriorly directed processes that articulate with skeletal elements of the dorsal fin. 
Description. Dorsal, lateral and ventral views in Fig. 4 illustrate body shape and positions of fins and barbels. Morphometric and meristic data for holotype (ANSP 168817) and 10 syntopic paratypes (ANSP 172504) are summarized in Table 1. Head depressed with only slight depression between orbits. Skull ornamentation well developed with paired series of bony knobs beginning behind eyes, converging on occiput and continuing on dorsal lamina of Weberian complex and middle nuchal plate. All bony knobs approximately equal in size. Anterior and posterior cranial fontanels present and separated by bony epiphyseal bar formed by frontals (Fig. 3). Integument covered with small unculiferous tubercles, those on posterior body in longitudinal rows; mid-dorsal row well defined; 2-3 well-defined rows on each side of caudal peduncle; several poorly-defined rows ventrally (Fig. 4). Caudal peduncle slender, round in cross section, tapering to caudal fin.

Mouth terminal, anterior limits of upper and lower jaws approximately equal. Premaxilla with 5-6 rows of acicular teeth and lacks posterolateral process. Dentary with 12-15 rows of teeth restricted to patch near symphysis of lower jaw (Fig. 1). Anterior nostril tubular, located at tip of snout, projecting beyond upper lip. Posterior nostril simple without flap or barbel, opening anteromedial to eye. Eye without free orbital rim. All barbels simple, unbranched; maxillary barbel reaching pectoral spine insertion. Posterolateral mental barbel at least twice as long as anteromedial mental barbel. Gular fold absent, branchiostegal membranes united to each other and to isthmus, 5 branchiostegal rays (Fig. 1). Opercular opening reduced to small valvular slit on ventral surface just anterior to pectoral spine insertion.

Gill rakers absent on all branchial arches. Pharyngeal teeth well developed on upper tooth plate; 1 or 2 rows of teeth on lower tooth plates. First and second hypobranchials well ossified; fourth pharyngobranchials absent. Parurohyal triangular with slight dorsal keel.

Openings of sensory canals on head darkly pigmented. Infraorbital canal exits sphenotic (Fig. 3) and passes anteriorly beyond eye, bearing up to four pores (not figured). Lateral-line canal truncated just posterior of parapophyses of fifth vertebra and anterior to dorsal-fin origin. A few individual isolated pores scattered more posteriorly, but never connected to main lateral-line canal.

Dorsal fin without spinelet; consists of relatively flexible spine and four soft rays. Dorsal-fin membrane not adnate with body. Anterior nuchal plate and supraneural absent. Middle nuchal plate ornamented with a single bony knob. Adipose fin absent. Anal fin with 5-7 soft rays (6 in holotype), anal-fin membrane not adnate with body. Pectoral fin with robust spine and 5 soft rays. Shaft of pectoral spine curved with serrations along both pre-axial and post-axial margins. Intact pectoral spine with flexible tip. Axial pore present. Postcoracoid process of pectoral girdle extends slightly past postcleithral process in lateral view. Pelvic fin with 6 soft rays, second and third rays longest, not reaching anal-fin origin, no pelvic splint. Caudal fin with 10 principal

Table 1. Summary of morphometric measurements and meristic counts for Pseudobunocephalus lundbergi (N=11; Holotype, ANSP 168817, and 10 syntopic Paratypes, ANSP 172504). Standard length expressed in mm. All other measurements expressed in percent of SL. Meristic data for holotype is identified by a * superscript.

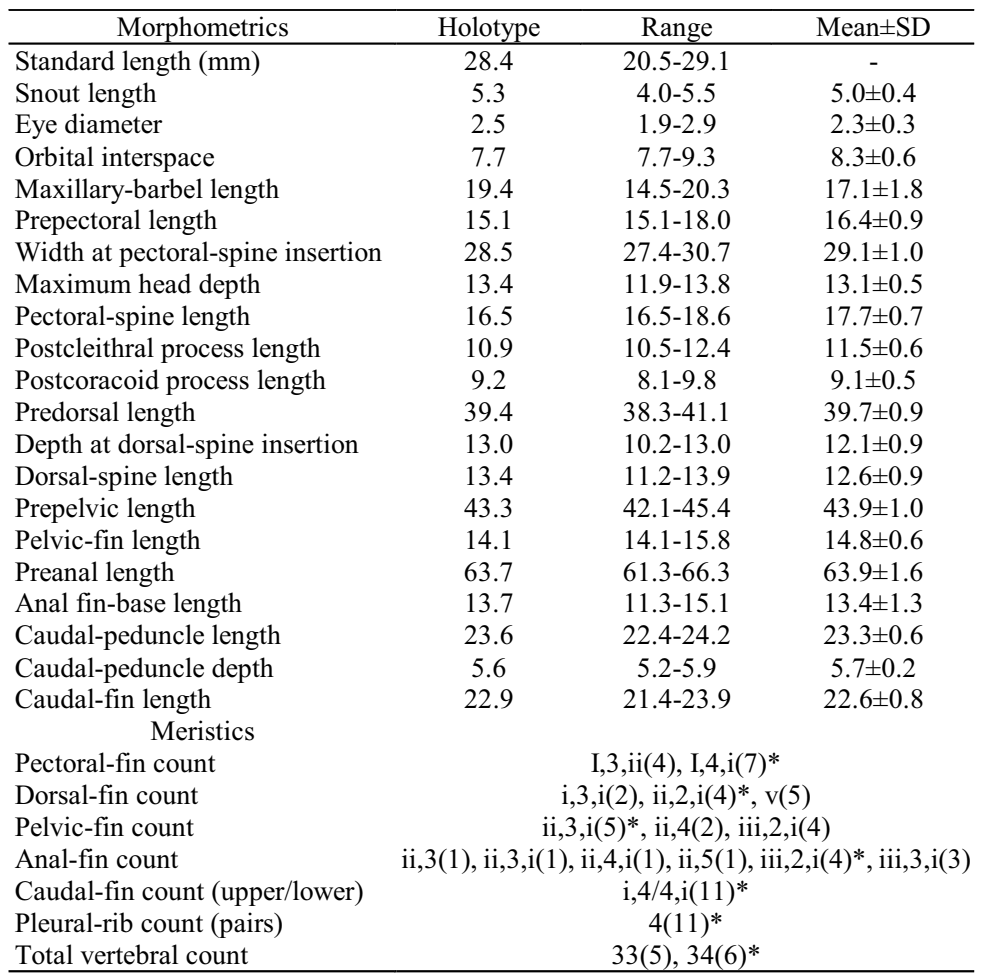


rays plus one upper and one lower procurrent ray. Caudal-fin margin rounded with outermost principal rays unbranched and shorter than branched principal rays.

Total vertebrae 33-34 (34 in holotype). Vertebrae 6-9 bearing ribs; dorsal-fin pterygiophores associated with Weberian complex (vertebrae 1-5) and vertebrae 6-11. Dorsal lamina of Weberian complex ornamented with series of three bony knobs. Parapophyses of fourth vertebra form broad lamina over swim bladder. Parapophysis of fifth vertebra long, curved anteriorly and extended laterally to body surface. Parapophyses of fourth and fifth vertebrae separated by deep notch (Fig. 3). No horizontal bony lamina developed on precaudal, caudal or ural centra. Hemal spines simple, not bifid, on vertebrae articulating with anal-fin pterygiophores.

Color in alcohol. Pigmentation variable with two distinct color morphs, one dark (Fig. 4) and one light. Dark morph with head light brown and irregularly mottled with darker pigment; overall body light brown with three poorly defined dark saddles, first beneath dorsal fin, and two more on posterior body. Individual unculiferous tubercles may be unpigmented or darkly pigmented giving speckled appearance to body. Ventral sur- face light brown with dark pigment concentrated in unculiferous tubercles. All fins and barbels mottled with dark pigment. Light morphs have similar pigmentation pattern to dark morphs but lack series of dark saddles on dorsal surface.

Size and sexual dimorphism. Specimens range from 19.5-30.0 $\mathrm{mm}$ SL. The largest specimens examined are females with ripening ova ( $0.5 \mathrm{~mm}$ in diameter). No observed dimorphism of body ornamentation, fins or pigmentation.

Distribution. Pseudobunocephalus lundbergi is currently known from just a few localities in the lower río Caura (type locality), upper río Apure, and río Meta (Fig. 5), but is likely more widely distributed within the río Orinoco basin of Colombia and Venezuela.

Etymology. The specific name is patronymic in honor of Dr. John G. Lundberg of The Academy of Natural Sciences of Philadelphia. Lundberg served as the author's Ph.D. advisor, and has made numerous contributions to the field of Neotropical ichthyology and the systematics of siluriform and gymnotiform fishes.

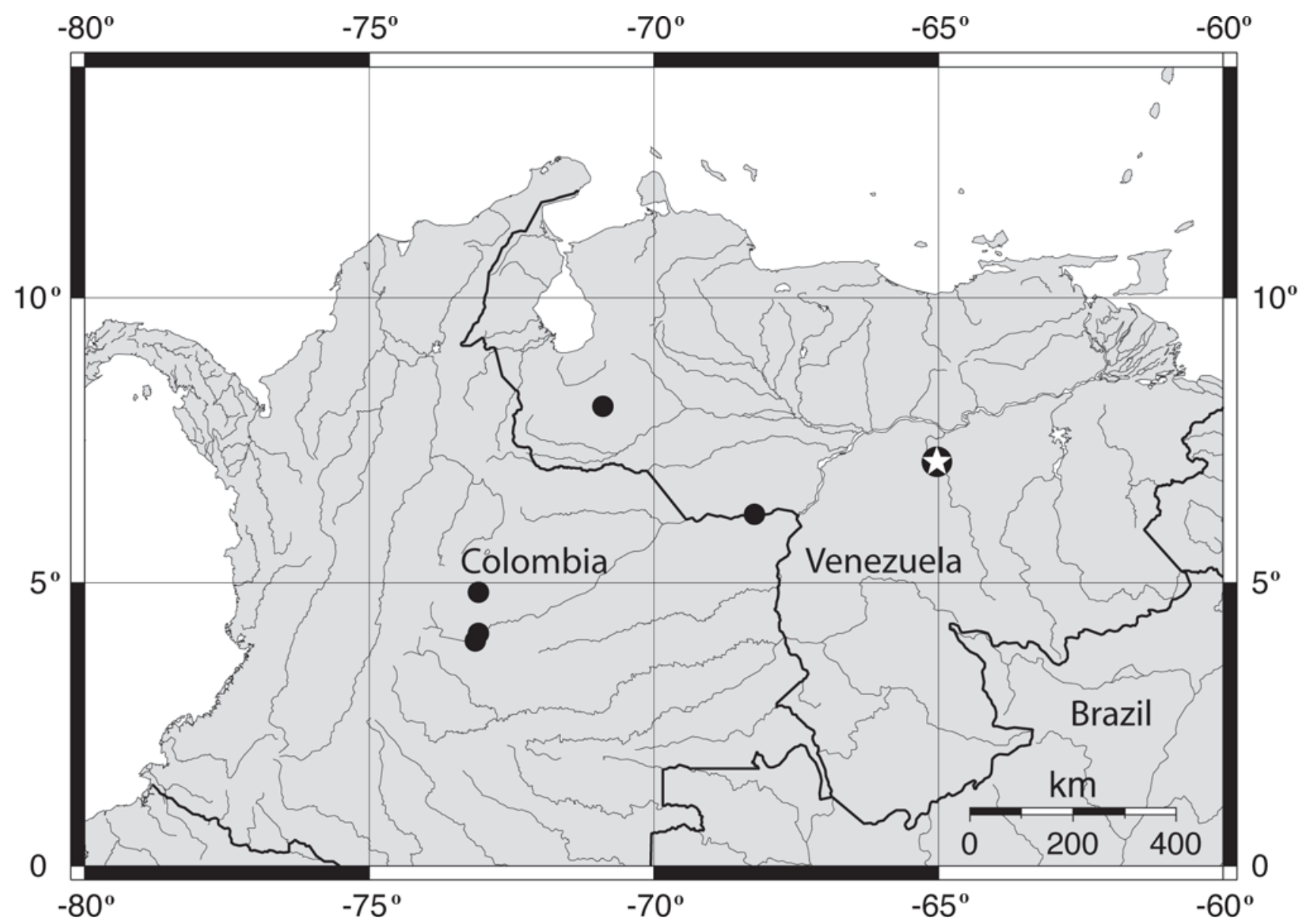

Fig. 5. Distribution map for Pseudobunocephalus lundbergi with the type locality indicated by a star symbol. 


\section{Discussion}

In overall appearance, Pseudobunocephalus most closely resembles Acanthobunocephalus, a monotypic aspredinid genus endemic to the upper Orinoco and Casiquiare systems. Acanthobunocephalus, however, can readily be distinguished from Pseudobunocephalus, since it is the only aspredinid that possesses a lockable dorsal spine. This feature is readily apparent even in the smallest specimens less than $12 \mathrm{~mm}$ SL.

Based on the author's unpublished phylogenetic analysis of the Aspredinidae (Friel, 1994), Pseudobunocephalus is the sister group to all other Aspredinidae. In addition to the derived characters that support monophyly of this genus, Pseudobunocephalus also retains several primitive character states for aspredinids including: ossified second hypobranchials; lack of bony horizontal lamina on any precaudal or caudal vertebrae; no bifid hemal spines articulating with anal-fin pterygiophores; and little or no contact between the parapophyses of vertebrae 4 and 5 .

Furthermore, $P$. lundbergi appears to be the sister taxon to all other species in this genus and lacks several derived features seen it its congeners. All other Pseudobunocephalus species ( $P$. amazonicus, $P$. bifidus, $P$. iheringii, $P$. quadriradiatus, and $P$. rugosus) share several derived features: the infraorbital canal exits from frontal and does not to pass anterior to the eye; the presence of a single large cranial fontanel between the paired frontals and sphenotic extending from mesethmoid anteriorly to supraoccipital posteriorly (i.e., absence of an epiphyseal bar formed by the frontals); premaxilla with a distinct posterolateral limb; and the lack of any contact or articulation between first dorsal-fin pterygiophore and the Weberian complex.

Material examined: Acanthobunocephalus nicoi: Venezuela: Amazonas: AMNH 230865, 7, 14.1-16.7 mm SL, río Coracora; AMNH 230889, 107, 16.3-18.0 mm SL, río Coracora; ANSP 160698, 1, $11.8 \mathrm{~mm}$ SL, río Sipapo; ANSP 168816, 3, 12.6-13.0 mm SL, caño of río Casiquiare; MCNG 21843, 9 (7 alcohol, 2 C\&S), 14.519.7 mm SL, río Sipapo; MCNG 29000, Holotype, $16.1 \mathrm{~mm} \mathrm{SL}$, río Sipapo. Pseudobunocephalus amazonicus: Bolivia: USNM 338697, 11, 20.0-26.0 mm SL, Ballivia, río Matos, $48 \mathrm{~km}$ E of San Borja; AMNH 39880, 1, 20.0 mm SL, Beni, río Itenez; UF 80214, 1, $27.5 \mathrm{~mm}$ SL, Beni, Cercado, arroyo San Javier; UMMZ 204301, 5, 20.0-20.5 mm SL, Beni, río Itenez; UMMZ 205164, 5, 19.5-26.0 mm SL, Beni, río Itenez; Brazil: INPA 6530, 2, 24.5-31.0 mm SL, Amazonas; MZUSP 9678, 3, 23.0-25.0 mm SL, Amazonas, Codajás; MCZ 75986, 1, 28.0 mm SL, Amazonas, lago Badajos; INPA 6522, 2, 27.5-28.0 mm SL, Amazonas, rio Javari; MCZ 7979, 6, 26.528.0 mm SL, Amazonas, rio Javari; MCZ 7980, 1, $25.3 \mathrm{~mm} \mathrm{SL}$, Amazonas, Tabatinga; FMNH 105328, 1, 22.0 mm SL, Rondônia, rio Guaporé, Maciel; Colombia: UF 26219, 1, $32.5 \mathrm{~mm} \mathrm{SL}$, Amazonas, Leticia; UF 33848, 1, 35.0 mm SL, Amazonas, Leticia; USNM 220851, 3, 37.0-44.5 mm SL, Amazonas, Leticia; Peru: AMNH 78107, 9, 28-44 mm SL, Loreto, río Tahuayo; AMNH 78105, 10, 24-43, Loreto, río Yarapa; CAS-SU 36202, 1, $24.5 \mathrm{~mm}$ SL, Loreto, Pevas, río Ampiyacu. Pseudobunocephalus bifidus: Bolivia: CAS 31466, 1, 35.4 mm SL, Beni, lago Rogoagua; CAS 31467, 1, 28.8 mm SL, lago Rogoagua; AMNH 39837, 5, 24.5-27.0, río Itenez; AMNH 57016, 1, $24.5 \mathrm{~mm} \mathrm{SL}$, río Itenez; UMMZ 204301, 5, 25.5-36.5, Beni, río Itenez; USNM 305861, 42, 27.036.0 mm SL, Beni, río Maniqui; Brazil: MZUSP 30708, 11, 24.250.0 mm SL, Acre, Tarauacá; MZUSP 23398, Brazil: Amazonas, Fonte Boa; INPA 6522, 1, 42.5 mm SL, Amazonas, rio Javari; USNM 191561, 1, 55.2 mm SL, Goiás, Aruana; INPA 6532, 4, 23.5-25.2 mm SL, Pará, Itupiranga; MZUSP 22796, 1, 30.4-32.0 mm SL, Pará, Canindé; MZUSP 30709, 1, 25.3 mm SL, Rondônia, rio Machado; Ecuador: FMNH 99484, 1, 30.5 mm SL, Napo, río Cuyabeno; Peru: AMNH 78102, 5, 38.0-42.5, Loreto, río Tahuayo; CAS 35106, 4, 33.0-43.0 mm SL, Loreto, Yurimaguas; USNM 300984, 1, 50.5 mm SL, Madre de Dios, Manu; USNM 302707, 1, $26.0 \mathrm{~mm}$ SL, Madre de Dios, Manu. Pseudobunocephalus iheringii: Argentina: CAS-SU 40100, 1, Buenos Aires, Buenos Aires; Brazil: MCZ 31583, Holotype of Bunocephalus salathei, 1, $39.0 \mathrm{~mm}$ SL, Minas Gerais, Morro Ajudo; CAS-SU 24072, 1 Paratype of Bunocephalus salathei, $25.0 \mathrm{~mm}$ SL, Minas Gerais, Morro Ajudo; USNM 92975, 2 Paratypes of Bunocephalus salathei, 25.0-26.0 mm SL, Minas Gerais, Morro Ajudo; CAS 53521, 1, 44.0 mm SL, Rio de Janeiro, Capivary; USNM 301690, 8, 41.2-48.0 mm SL, Rio de Janeiro, rio Regane; CAS 31470, 3, 16.0-28.7 mm SL, Rio Grande Do Sul, rio Camaquã; FMNH 70628, 23, 13.0-47.0 mm SL, Rio Grande do Sul, Cacequi; FMNH 88242, 6, 34.0-47.0 mm SL, Rio Grande do Sul, Uruguaiana; MZUSP 40966, 2, 22.0-25.0 mm SL, Rio Grande do Sul, Itaqui; MZUSP43337, 1, 44.0 mm SL, Rio Grande do Sul, Itaqui; MZUSP 23165, 1, 28.0 mm SL, Rio Grande do Sul, São Leopoldo; MZUSP 23187, 1, 28.0 mm SL, Rio Grande do Sul, São Leopoldo; MZUSP 23191, 2, 41.0-44.0 mm SL, Rio Grande do Sul; São Leopoldo; Paraguay: UMMZ 206226, 2, 41.045.0 mm SL, Alto Parana; UMMZ 206289, 4, 35.0-41.0 mm SL, Canendiyu; USNM 181480, 1, $23.0 \mathrm{~mm}$ SL, Misiones, Florida; Uruguay: FMNH 70629, 8, 29.0 -48.0 mm SL, Treinta y Tres, Estancia Jeffries. Pseudobunocephalus quadriradiatus: Peru: Loreto: AMNH 96958, 4, 16.7-22.7 mm SL, small brook half way between Hamburgo and Santa Elena; MHNG 2157.12, Holotype, $32.0 \mathrm{~mm}$ SL, río Samiria, cocha Shinguita. Pseudobunocephalus rugosus: Brazil: MZUSP 28341, 1, $17.0 \mathrm{~mm}$ SL, Mato Grosso, rio Pixai; CAS 35241, 3, 20.8-21.5 mm SL, Mato Grosso do Sul, Corumbá; FMNH 52615, 1, 22.0 mm SL, Mato Grosso do Sul, Corumbá; MZUSP 36433, 2, 22.0-23.0 mm SL, Mato Grosso do Sul, Corumbá; MZUSP 4461, 2, 19.0-22.0 mm SL, MT, Santo Antônio do Leverger; Paraguay: UMMZ 205875, 2, 17.0-20.0 mm SL, Central; UMMZ 205514, 1, 30.0 mm SL, Central, río Salado; UMMZ 207820, 8, 22.0-38.0 mm SL, Conception; UMMZ 207894, 3, 15.0-25.0 mm SL, Conception, río Aquidaban at Paso Horqueta; AMNH 59797, 9, 22.0-25.0 mm SL, Presidente Hayes, Estancia la Golondrina; UMMZ 206973, 6, 17.0-30.0 mm SL, Presidente Hayes, Estancia la Golondrina; UMMZ 207567, 3, 27.030.0 mm SL, Presidente Hayes, río Pilcomayo; USNM 232383, 3 , 19.0-27.0 mm SL, Presidente Hayes, $44 \mathrm{~km}$ west of Concepcion.

\section{Acknowledgments}

The All Catfish Species Inventory (NSF DEB-0315963) provided support for completion of this publication. I also thank the following institutions and individuals for assistance with loans of fishes used in this study: AMNH (Barbara Brown, Scott Schaefer, and Melanie Stiassny); ANSP (John Lundberg, Mark Sabaj Pérez, and William Saul); CAS (Dave Catania, William Eschmeyer, and Tomio Iwamoto); 
FLMNH (George Burgess and Rob Robins); FMNH (Mary Anne Rogers and Mark Westneat); INPA (Lúcia Rapp PyDaniel and Jansen Zuanon); MBUCV (Hector Lopez, Antonio Machado-Allison, and Francisco Provenzano); MCNG (Donald Taphorn); MCZ (Karsten Hartel); MZUSP (Heraldo Britski, Naércio Menezes, and Osvaldo Oyakawa); UMMZ (Douglas Nelson); and USNM (Susan Jewett, Sandra Raredon, Jeff Williams, and Richard Vari).

\section{Literature Cited}

Boulenger, G. A. 1891. An account of the siluroid fishes obtained by Dr. H. von Ihering and Herr Sebastian Wolff in the Province Rio Grande do Sul, Brazil. Proceedings of the Zoological Society of London, 1891: 231-235.

Eigenmann, C. H. \& W. R. Allen. 1942. Fishes of Western South America. I. The Intercordilleran and Amazonian lowlands of Peru. II. The high pampas of Peru, Bolivia, and Northern Chile; with a revision of the Peruvian Gymnotidae, and of the genus Orestias. University of Kentucky. 494p.

Eigenmann, C. H. \& C. H. Kennedy. 1903. On a collection of fishes from Paraguay, with a synopsis of the American genera of cichlids. Proceedings of the Academy of Natural Sciences of Philadelphia, 55(2): 497-537.

Eigenmann, C. H., W. L. McAtee \& D. P. Ward. 1907. On further collections of fishes from Paraguay. Annals of the Carnegie Museum, 4: 110-157.

Ferraris, C. J., Jr. 2007. Checklist of catfishes, recent and fossil (Osteichthyes: Siluriformes), and catalogue of siluriform primary types. Zootaxa, 1418: 1-628.

Friel, J. P. 1994. A phylogenetic study of the Neotropical banjo catfishes (Teleostei: Siluriformes: Aspredinidae). Unpublished Ph.D. Dissertation, Duke University, Durham. 256p.
Friel, J. P. 1995. Acanthobunocephalus nicoi, a new genus and species of miniature banjo-catfish from the upper Orinoco and Casiquiare Rivers, Venezuela (Siluriformes: Aspredinidae). Ichthyological Explorations of Freshwaters, 6(1): 89-95.

Friel, J. P. 2003. Family Aspredinidae (Banjo catfishes). Pp. 261267. In: R. Reis, S. Kullander \& C. J. Ferraris, Jr. (Eds.). Check List of the Freshwater Fishes of South and Central America. EDIPUCRS, Porto Alegre. 742p.

Güntert, H. 1942. Beschreibung einiger zum Teil noch unbekannter südamerikanischer Siluriden aus dem Naturhistorischen Museum in Basel. Zoologischer Anzeiger, 138: 27-40.

Leviton, A. E., R. H. Gibbs, Jr., E. Heal \& C. E. Dawson. 1985. Standards in herpetology and ichthyology: Part I. Standard symbolic codes for institutional resource collections in herpetology and ichthyology. Copeia, 1985(3): 802-832.

Mees, G. F. 1989. Notes on the genus Dysichthys, subfamily Bunocephalinae, family Aspredinidae (Pisces, Nematognathi). Proceedings of the Koninklijke Nederlandse Akademie van Wetenschappen, 92(2): 189-250.

Miranda Ribeiro, P. 1944. Uma nova espécie para o gênero Bunocephalus Kner, 1855. Boletim do Museu Nacional, 13: 13.

Myers, G. S. 1927. Descriptions of new South American freshwater fishes collected by Dr. Carl Ternetz. Bulletin of the Museum of Comparative Zoology, 69(3): 107-135.

Myers, G. S. 1960. The genera and ecological geography of the South American banjo catfishes, family Aspredinidae. Stanford Ichthyological Bulletin, 7(4): 132-139.

Walbaum, J. J. 1792. Petri Artedi Sueci Genera Piscium. In Quibus Systema Totum Ichthyologiae Proponitur cum Clas sibus, Ordinibus, Generum Characteribus, Specierum Differentiis, Observationibus Plurimis. Redactis Speciebus 242 ad Genera 52. Ichthyologiae, pars iii, Grypeswaldiae, impensis A. F. Röse, $723 \mathrm{p}$. 